\title{
A laboratory study on digestive processes in the Antarctic krill, Euphausia superba, with special regard to chitinolytic enzymes
}

Accepted: 4 October 1998

\begin{abstract}
Feeding experiments of 9, 14 and 20 days duration were carried out on the Antarctic krill, Euphausia superba. Two groups were fed with the chitinous diatom Cyclotella cryptica and the non-chitinous green algae Dunaliella bioculata, respectively. A control group remained unfed. The time courses of the activities of endo- and exochitinase in the stomach and the midgut gland were compared with those of the digestive enzymes protease, cellulase (1,4- $\beta$-D-glucanase) and laminarinase (1,3- $\beta$-D-glucanase). Specific activities of all enzymes were higher in the stomach than in the midgut gland. Characteristic time courses of activity were evident after 4 days. In starved animals, enzyme activities decreased to a minimum after 4 days and recovered within 14 days to initial values. In the stomach, the activities of endo- and exochitinase increased when krill were fed on Cyclotella. For animals fed with Dunaliella, activities stayed constant or decreased slightly. The results confirm chitinases as digestive enzymes and, therefore, the capability of krill to utilize various food sources.
\end{abstract}

\section{Introduction}

The Antarctic ocean is an extreme environment and organisms living there require biological specializations and, particularly, physiological and biochemical adaptations. An important organism in the Antarctic ecosystem is the Antarctic krill, Euphausia superba. Krill represent the main food source for predators such as whales, seals and birds. As filter feeders, krill feed mainly on phytoplankton. Primary production in Antarctic waters is, however, characterized by high seasonal and spatial variation (El-Sayed and Taguchi 1981; El-

R. Saborowski $(\bowtie) \cdot$ F. Buchholz

Biologische Anstalt Helgoland-AWI, Meeresstation, D-27483 Helgoland, Germany

e-mail: RSaborowski@awi-bremerhaven.de,

Tel.: + 49-4725-819326, Fax: +49-4725-819369
Sayed and Weber 1982) and, potentially, E. superba can also change to carnivorous feeding at low phytoplankton densities or during the Antarctic winter (Price et al. 1988; Lancraft et al. 1991; Huntley et al. 1994; Atkinson and Snÿder 1997; Pakhomov et al. 1997). Krill are able to graze on patchy food sources very efficiently (Hamner et al. 1983). Appropriate activity levels of digestive enzymes are a prerequisite to ensure rapid digestion and resorption under a variable food regime.

In addition to several glucanases and proteases (Mayzaud et al. 1985; McConville et al. 1986), high activities of endo-chitinase (poly- $\beta$-1,4-(2-acetamido2 -deoxy)-D-glucosid-glucanohydrolase) and $N$-acetyl- $\beta$ D-glucosaminidase (here NAGase) have been found in the digestive tract of krill (Buchholz 1989). Both enzymes are also present in the integument, where they show moult-related patterns of activity (Buchholz and Buchholz 1989). In the stomach and the midgut gland (hepatopancreas), however, the activities are not affected by the moult cycle. Previous field investigations support the hypothesis of a digestive function of both enzymes (Buchholz and Saborowski 1996).

Chitin consists of amino sugars and is, therefore, of considerable nutritive value. Diatoms of the genus Thalassiosira contain substantial amounts of chitin as "spines" (McLachlan et al. 1965) and at certain times can dominate the Antarctic phytoplankton (Johansen and Fryxell 1985; V. Smetacek, personal communication). Krill could, therefore, make use of this rich food source, and the presence of a set of readily available enzymes would enhance their physiological capability. A possible induction of the chitinases, similar to that reported for other enzymes (Mayzaud and Conover 1976; Cox and Willason 1981), would demonstrate their relation to the food supply, and identify them as digestive enzymes.

The aim of the present work was to study the response of chitinases in the krill's digestive organs to different feeding conditions in comparison to various typical digestive enzymes. The protocol included feeding chitinous and non-chitinous algae, respectively. The 
activity patterns of the chitinases were investigated in relation to protease, cellulase, laminarinase, gut fullness and the gross composition of the diet. The results are discussed in relation to the digestion physiology of krill and Antarctic ecological conditions.

\section{Materials and methods}

\section{Phytoplankton cultures}

Strains of the chitinous diatom Cyclotella cryptica (Bacillariophyceae, Centrales) and the green alga Dunaliella bioculata (Chlorophyceae) were obtained from the algal collection of the University of Göttingen (Dr. Schlösser). Both species were cultured during the expedition Met 11/4 (21.12.1989-18.01.1990) on board the research vessel FS Meteor. Semi-batch cultures were maintained at $20-25{ }^{\circ} \mathrm{C}$ in a seawater/nutrient solution according to Guillard and Ryther (1962) and were exposed to a 16:8 h light:dark cycle.

For the determination of the dry weight of algae, $800 \mathrm{ml}$ of the culture was centrifuged for $10 \mathrm{~min}$ at $4000 \mathrm{~g}$. Several pellets were transferred into $1.5-\mathrm{ml}$ reaction tubes and were again centrifuged for $10 \mathrm{~min}$ at $8000 \mathrm{~g}$. The supernatants were removed and the remaining material was lyophilized to constant weight (Christ, Beta A).

\section{Determination of substrate concentrations in the cultured algae}

Soluble protein and the substrates cellulose and laminarin were determined and expressed relative to the dry weight of algae samples. Lyophilized samples of algae were resuspended in a total volume of $1 \mathrm{ml} \mathrm{0.2} \mathrm{M} \mathrm{Citrate-Phosphate} \mathrm{Buffer} \mathrm{(CPB),} \mathrm{pH} \mathrm{5.5,} \mathrm{and}$ homogenized on ice by ultrasonication (Branson, Sonifier B12) for $3 \times 15 \mathrm{~s}$ with a break of $20 \mathrm{~s}$ each time. The cell-disrupter was adjusted to $30 \%$ of maximal energy. Algal chitin as "spines" was isolated from fresh cells according to McLachlan et al. (1965) and stored at $-80{ }^{\circ} \mathrm{C}$ for further analysis. For D. bioculata, which does not contain chitinous spines, lyophilized algae were analysed.

Soluble protein was determined according to Bradford (1976) using the BioRad microassay.

Cellulose $(1,4-\beta$-D-glucan) was hydrolysed by cellulase (Sigma $\mathrm{C}$-2415). The reducing sugars were determined using $3^{\prime} 5^{\prime}$-dinitrosalicylic acid. In order to denature algal enzymes, the samples were heated for $10 \mathrm{~min}$ at $100{ }^{\circ} \mathrm{C}$ prior to analysis. A $100-\mu$ l sample was added to $100 \mu$ of $0.2 \mathrm{M} \mathrm{CPB}, \mathrm{pH} 5.5$ in $1.5-\mathrm{ml}$ reaction tubes. The reaction was initiated with $100 \mu \mathrm{l}$ cellulase solution $\left(1 \mathrm{U} \mathrm{ml}^{-1}\right.$ in $0.2 \mathrm{M} \mathrm{CPB}, \mathrm{pH}$ 5.5). The tubes were incubated for $2 \mathrm{~h}$ at $37^{\circ} \mathrm{C}$, with continuous stirring. After incubation, the tubes were centrifuged for $5 \mathrm{~min}$ at $15,000 \mathrm{~g}$. The supernatant $(250 \mu \mathrm{l})$ was added to $250 \mu \mathrm{l}$ of $0.1 \mathrm{M} \mathrm{K} / \mathrm{Na}-\mathrm{P}-\mathrm{Buffer}, \mathrm{pH}$ 6.8. After the addition of $3^{\prime} 5^{\prime}$ dinitrosalicyl acid solution and $5 \mathrm{~min}$ of incubation at $100{ }^{\circ} \mathrm{C}$, the reaction was stopped by cooling in ice-water. The absorption was read at $546 \mathrm{~nm}$. Standards with cellulose (Sigma C-6288) suspended in $0.2 \mathrm{M} \mathrm{CPB}, \mathrm{pH} 5.5$, were run in parallel.

Laminarin-like glucans (1,3- $\beta$-D-glucans) were determined as described for cellulose, except that laminarinase (Sigma L-5272) with an activity of $1 \mathrm{U} \mathrm{ml}^{-1}$ replaced the cellulase. Standards were run in parallel with laminarin (Sigma L-9634).

The amount of chitin in algae was measured by acid hydrolysis of isolated spines and subsequent determination of amino sugars. For the acid hydrolysis, the dried spines were resuspended in $0.5 \mathrm{ml}$ distilled water by sonication (Branson, Sonifier B12) for $3 \times 15 \mathrm{~s}$, interrupted by breaks of $20 \mathrm{~s}$. Fifty microlitres of the suspension was incubated with $950 \mu \mathrm{l}$ of $6 \mathrm{~N} \mathrm{HCl}$ at $100{ }^{\circ} \mathrm{C}$ for $6 \mathrm{~h}$. After incubation, the solution was transferred into small glass vials and evaporated under a stream of air. The residue was dissolved in $500 \mu \mathrm{l}$ borate buffer, $\mathrm{pH}$ 9.2. Fifty microlitres of this solution were assayed for amino sugars according to Morgan and Elson (1934), modified by Saborowski et al. (1993). Blanks were run in parallel as well as standards containing purified chitin (Sigma C-3641).

\section{Collection of krill}

Antarctic krill, E. superba, were caught north of the Antarctic peninsula during the cruise Met 11/4 (21 December 1989 to 18 January 1990). Sampling was carried out with a Bongo net $(2 \times 63 \mathrm{~cm}$, mesh width $320 \mu \mathrm{m})$ near Elephant Island $\left(60^{\circ} \mathrm{S} 57.75\right.$ $\left.27^{\circ} \mathrm{W} 07.50\right)$ and a Rectangular Midwater Trawl, RMT $1+8$ (Roe and Shale 1979) near King George Island $\left(62^{\circ} \mathrm{S} 05.95\right.$ $57^{\circ} \mathrm{W} 39.00$ and $\left.62^{\circ} \mathrm{S} 44.7759^{\circ} \mathrm{W} 06.43\right)$. All samples were obtained from depths between $60 \mathrm{~m}$ and the surface. Immediately after capture, the animals were transferred into tanks containing fresh, aerated seawater. After $24 \mathrm{~h}$ the most active animals were selected for the feeding experiments.

\section{Feeding experiments}

In order to cover a maximum range of experimental time scales, three feeding experiments of different duration were carried out Within each experiment, three groups of animals were maintained separately in aerated tanks. One group was fed with the diatom $C$. cryptica, the second with the green alga D. bioculata, and the third group was not fed. The experiments were carried out at 0 $2{ }^{\circ} \mathrm{C}$ and illumination was provided on a $16: 8 \mathrm{~h}$ light:dark cycle. The maintenance tanks (closed systems) had been filled with fresh seawater from the ship's seawater supply system. This surface water had been filtered through 3- $\mu \mathrm{m}$ membrane filters (Sartorius, 11302 293-G) using a pressure filter system (Sartorius, SM 16277). During the experiments the water in the tanks was exchanged at least every other day. Faecal pellets and moults were removed frequently. Krill were frozen and stored at $-75^{\circ} \mathrm{C}$ until analysis. Feeding with algae started 1 day after the tanks had been stocked with krill. Fifty millilitres of algal culture (approximately $1.75 \mathrm{mg}$ dry weight, DW) were added per animal per day.

Experiment 1 lasted for 20 days and was carried out in three tanks of $40 \times 60 \mathrm{~cm}$ and 20 -cm height. Each tank was equipped with 24 PVC containers (volume 11 ), each containing 1 animal. The bottoms of the containers were punctured to ensure equal water levels in all containers and to expose the animals to the same water conditions. Experiment 2 (14 days) was carried out with 45 krill in each of 3 basins of $40 \times 30 \times 30 \mathrm{~cm}$. The animals were not separated as described above. In experiment 3 (9 days), 135 krill were maintained in each of 3 basins of $40 \times 60 \times 60 \mathrm{~cm}$. A subsample of 15 animals was removed after 2, 4, 6 and 9 days. The volume of the water was reduced proportionally after each sampling in order to maintain a constant density of krill.

Only a representative number of animals from each feeding experiment was analysed for enzyme activities. Thus, the numbers of animals used for feeding experiments and the numbers analysed differed in the three experiments.

\section{Enzyme determination}

The fullness of the three digestive organs, stomach, midgut gland and gut, was determined visually according to Morris et al. (1983) on frozen animals prior to the dissection of the stomach and the midgut gland for biochemical analysis. The organs were transferred into reaction tubes and $1 \mathrm{ml} 0.2 \mathrm{~mol} \mathrm{l}^{-1}$ of citrate/phosphate buffer (CPB, pH 5.5) was added. Homogenization was performed on ice with an ultrasonic cell disrupter (Branson, Sonifier B-12, microtip $101-148-063$ ) at $30 \%$ of maximum energy with three bursts of $15 \mathrm{~s}$ with a break of $20 \mathrm{~s}$ inbetween. The homogenates were centrifuged at $15,000 \mathrm{~g}$ and the supernatant was used for analysis. 
The activities of chitinase and NAGase were determined according to Saborowski et al. (1993). Activities of total protease, cellulase and laminarinase were determined as described by $\mathrm{Bu}-$ chholz and Saborowski (1996) and Donachie et al. (1995), respectively. Enzyme activities as referred to in the following were normalized to fresh weight $\left(\Delta \mathrm{A} \mathrm{min}^{-1} \mathrm{mg}^{-1}\right.$ fresh weight).

As a control, we also determined the specific activities of the enzymes investigated in the phytoplankton cultures. Fifty millilitres of culture suspension was centrifuged at $4000 \mathrm{~g}$. The pellets were resuspended in a small volume of culture medium and transferred into preweighed reaction caps $(1.2 \mathrm{ml})$. After centrifugation at $15,000 \mathrm{~g}$, the supernatant was discharged and the fresh weight of the algae was determined. The sediment was homogenized and processed as described for animal tissue samples.

\section{Statistics}

Pairwise comparison of data sets was performed with the MannWhitney $U$-test. The results are presented in the figures as means and $95 \%$ confidence intervals $(95 \% \mathrm{CI})$.

A rank-correlation analysis was carried out on the data of enzyme activity in the stomach and the midgut gland during experiment 3. The strength of the association was expressed by the Spearman correlation coefficients as calculated by the computer program SYSTAT (Wilkinson 1989). The significance level was set at $P \leq 0.05$.

\section{Results}

\section{Phytoplankton cultures}

The biomass of C. cryptica cultures was $34.8 \pm 1.6 \mathrm{mg}$ $\mathrm{DW}^{-1}$ and that of D. bioculata $38.3 \pm 2.1 \mathrm{mg} \mathrm{DW}^{-1}$ $(n=7)$. The amount of laminarinase digestible glucans was higher in $C$. cryptica $(8.7 \pm 0.9 \% \mathrm{DW})$ than in $D$. bioculata $(4.6 \pm 1.4 \% \mathrm{DW})$. The cellulose content was nearly identical in the two species: $21.0 \pm 3.1 \% \mathrm{DW}$ in C. cryptica and $20.2 \pm 1.9 \% \mathrm{DW}$ in D. bioculata. The water-soluble protein content of C. cryptica was $15.2 \pm 2.5 \% \mathrm{DW}$ and that of D. bioculata $12.5 \pm 0.6 \%$ DW. The amount of chitin in C. cryptica was $11.6 \pm$ $2.9 \%$ DW while no chitin was found in D. bioculata.

No significant activity of the enzymes investigated was found in the phytoplankton cultures. Low activities of chitinase in Cyclotella and Dunaliella and of laminarinase in Dunaliella cultures were recorded but these were within the range of error for the assay.

Morphometric data and organ colour index of maintained krill

The largest animals were used in experiment 1 (Table 1). Accordingly, the percentage of juveniles was smallest there. Specimens used in experiments 2 and 3 were obtained from the same catch and were, therefore, of similar length and weight.

The colour index of the digestive organs was related to the amount of food ingested during the feeding experiments (Fig. 1). The starved animals had significantly lower values than the fed animals. Within all experiments the values in fed animals were similar and ranged between 3 and 6 .

Enzyme activities

\section{Experiment 1 (Fig. 2)}

A control group was frozen immediately after the catch. Before feeding started, a further control group was frozen at time $t=0$. The experiment was terminated after 20 days.

Stomach chitinase and NAGase increased between capture and the beginning of feeding. After 20 days of the experiment chitinase and NAGase activities were significantly reduced in starved animals, but showed no distinct differences in animals fed Cyclotella or Dunaliella. A similar pattern was seen for the midgut gland, although in this case NAGase decreased significantly between capture and the start of the experiment. Animals fed with Cyclotella had higher chitinolytic activities than animals fed with Dunaliella.

In the stomach, protease and laminarinase activities of fed animals were higher than those in starved animals. Highest cellulase activities were evident in animals fed with Dunaliella. In the midgut gland, animals fed with Cyclotella had the highest activities of all three enzymes. Laminarinase activity in starved animals was higher than in animals fed with Dunaliella.

\section{Experiment 2 (Fig. 3)}

As in experiment 1 there was an increase in chitinase and NAGase between capture and the beginning of feeding. After 14 days there were only slight differences in chitinase activity between the three groups while NAGase was significantly higher in animals fed with Cyclotella than in animals fed with Dunaliella. In the midgut gland chitinolytic activities were significantly higher in animals fed with Dunaliella.

Stomach protease and cellulase levels were lower in animals fed with Dunaliella. Starved animals had slightly elevated levels of laminarinase. In the midgut gland, most enzyme activities of fed and starved animals were
Table 1 Length, fresh weight (means $\pm \mathrm{SD}$, each) and sex distribution (\% juveniles, females and males) of krill maintained in the feeding experiments

\begin{tabular}{lrllrll}
\hline & $n$ & $\begin{array}{l}\text { Length } \\
(\mathrm{mm})\end{array}$ & $\begin{array}{l}\text { Fresh } \\
\text { weight }(\mathrm{mg})\end{array}$ & \multicolumn{2}{l}{$\begin{array}{l}\text { Sex } \\
(\% \mathrm{j} / \mathrm{f} / \mathrm{m})\end{array}$} \\
\hline Experiment 1 & 60 & $39.3 \pm 4.2$ & $466.8 \pm 217.5$ & 5 & 54 & 41 \\
Experiment 2 & 25 & $34.3 \pm 1.9$ & $259.7 \pm 45.9$ & 20 & 37 & 43 \\
Experiment 3 & 135 & $34.2 \pm 1.9$ & $264.6 \pm 42.2$ & 19 & 33 & 48 \\
\hline
\end{tabular}


Fig. 1 Colour indices of the stomach $(S T)$, the midgut gland $(M G)$, and the gut $(G U)$ of animals used in the feeding experiments (means and 95\% CI, $n=4-16$ of individual organs)

Fig. 2 Activities of digestive enzymes in the stomach and the midgut gland of krill maintained in experiment 1 (20 days). Krill Dunaliella $(\mathrm{Du}$ - chitin) or fed with Cyclotella $(\mathrm{Cy}+$ chitin). The bar charts show means and $95 \%$ CI of 4-16 individual organs. Values sharing the same letter are not significantly different within the respective plot $(P \leq 0.05)$ were not fed $(H u)$, fed with
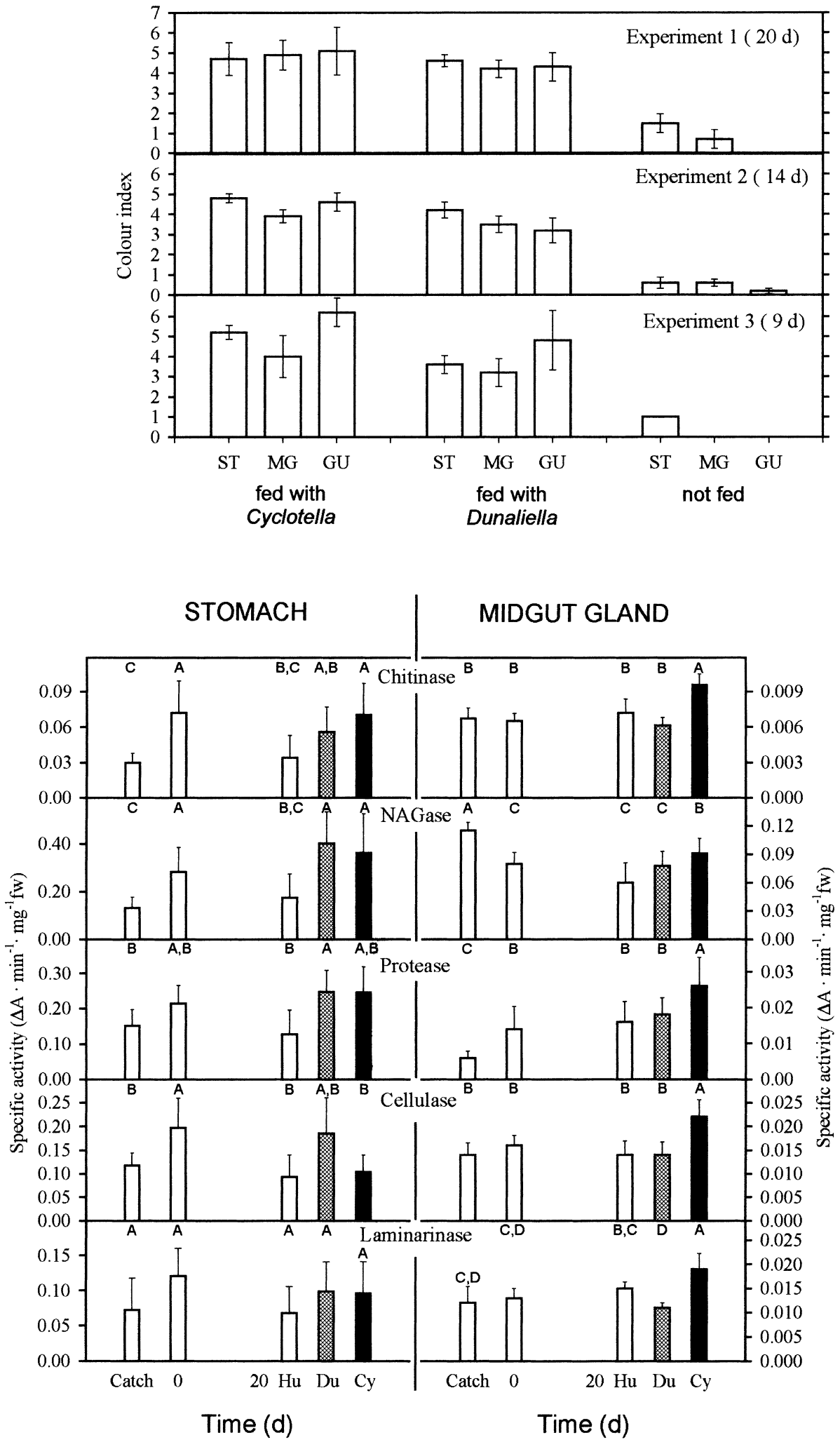

clearly higher than initial values. With the exception of protease, which was highest in starved animals, animals fed with Dunaliella had elevated activities at the end of the experiment which, however, were not statistically significant.

\section{Experiment 3 (Fig. 4)}

In experiment 3 samples were taken after capture, at the beginning of feeding, and then after 2, 4, 6 and 9 days of feeding. In the stomach there was a slight increase of 
Fig. 3 Activities of digestive enzymes in the stomach and the midgut gland of krill maintained in experiment 2 (14 days). Krill were not fed $(H u)$, fed with Dunaliella (Du - chitin) or fed with Cyclotella $(\mathrm{Cy}+$ chitin $)$. Means and $95 \%$ CI of five individual organs. Values sharing the same letter are not significantly different within the respective plot $(P \leq 0.05)$

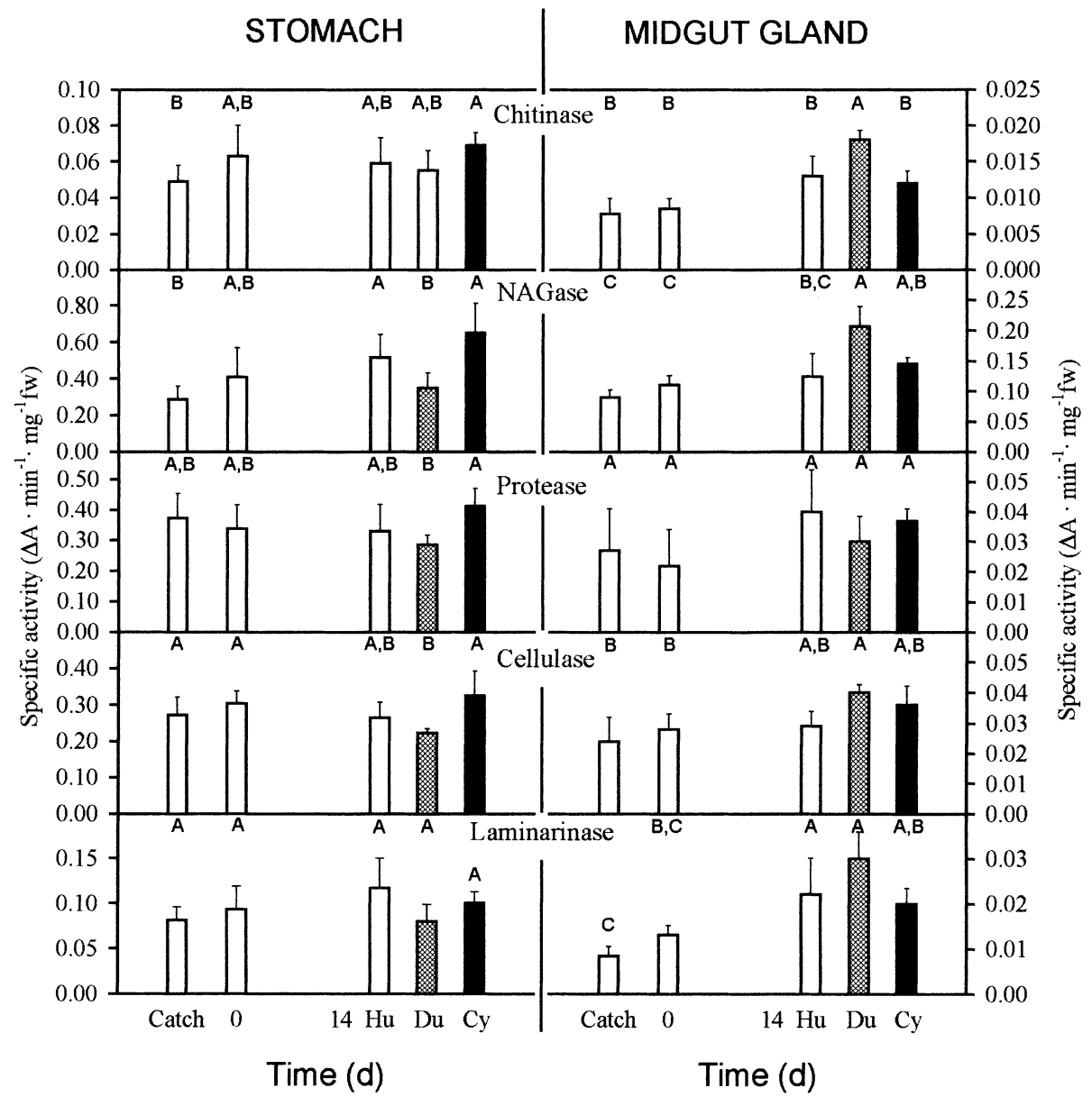

chitinase, as well as NAGase activity, between capture and the beginning of feeding as observed in experiments 1 and 2. In starved animals, chitinolytic activities decreased rapidly after $t=0$ and reached minimal values at the 4th day. Thereafter, the activities increased again and reached about $50 \%$ of the initial values. Chitinase and NAGase activity in animals fed with Dunaliella decreased continuously and, after 9 days, were not significantly different from those in starved animals. In contrast, activity in animals fed with Cyclotella increased and final values were significantly higher than in animals fed with Dunaliella or starved animals. Maximum activities were reached at the 6th day, after which chitinase dropped towards initial values, while NAGase remained at a high level.

In the midgut gland, the time courses of activity were less distinct. Chitinolytic activities were similar in groups fed with both algae, but starved animals showed decreased activities.

In general, protease and cellulase in the stomach showed similar patterns as the chitinolytic enzymes. Laminarinase increased strongly after 6 days in both the stomach and the midgut gland. In the midgut gland, the time courses of enzyme activity differed less than in the stomach. In starved animals a decrease of activity to the 4th day of the experiment was observed. In the fed animals, the distinct trends reported for the stomach could not be seen.

\section{Correlation analysis}

The correlation analysis between activity levels in the stomach and in the midgut gland in experiment 3 showed statistically significant correlations only for protease in starved animals and in animals fed with Dunaliella (Table 2). Most enzymes were only weakly correlated and some negative correlations also appeared.

The correlation analysis between all stomach enzymes within one feeding condition (Table 3) showed, for starved animals, statistically significant relations of chitinase to NAGase, protease and cellulase. Almost perfect correspondence was found for NAGase-protease, NAGase-cellulase, and for protease and cellulase. The other correlation coefficients were comparatively high and were always positive. In animals fed with Dunaliella, again all correlation coefficients were positive and comparatively high. Five enzymes matched significantly. The weakest correlations among the enzymes were found between NAGase-cellulase and NAGaselaminarinase. In animals fed with Cyclotella, the correlation coefficients were lower and some negative 
Fig. 4 Time courses of digestive enzymes in stomach and midgut gland of krill maintained in experiment 3 (9 days) $(\bigcirc$ not fed, circle partly filled fed with Dunaliella, fed with Cyclotella; means and $95 \% \mathrm{CI}, n=4-15$ individual organs)

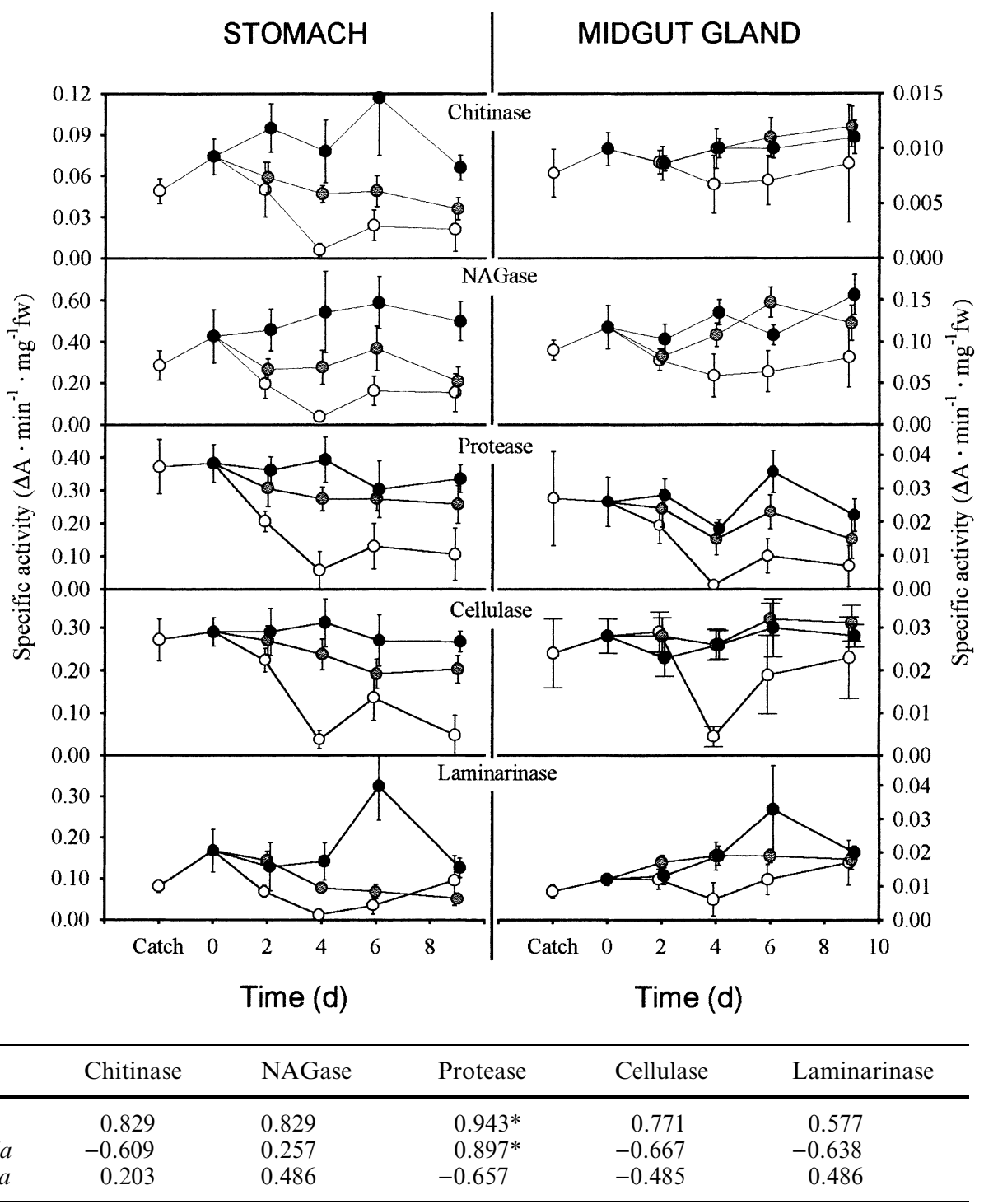

Table 2 Matrix of correlation coefficients $\left(r_{s}\right)$ of enzyme activities between the stomach and the midgut gland of $\mathrm{Eu}$ phausia superba under different feeding conditions in experiment 3 ( $n=6$, see Fig. 4)

\begin{tabular}{lclccc}
\hline & Chitinase & NAGase & Protease & Cellulase & Laminarinase \\
\hline Hunger & 0.829 & 0.829 & $0.943^{*}$ & 0.771 & 0.577 \\
Dunaliella & -0.609 & 0.257 & $0.897^{*}$ & -0.667 & -0.638 \\
Cyclotella & 0.203 & 0.486 & -0.657 & -0.485 & 0.486 \\
\hline
\end{tabular}

$* P<=0.05$

Table 3 Matrix of correlation coefficients $\left(r_{s}\right)$ between the enzyme activities in the stomach and in the midgut gland, respectively, of Euphausia superba under different feeding conditions in experiment $3(n=6$, see Fig. 4)

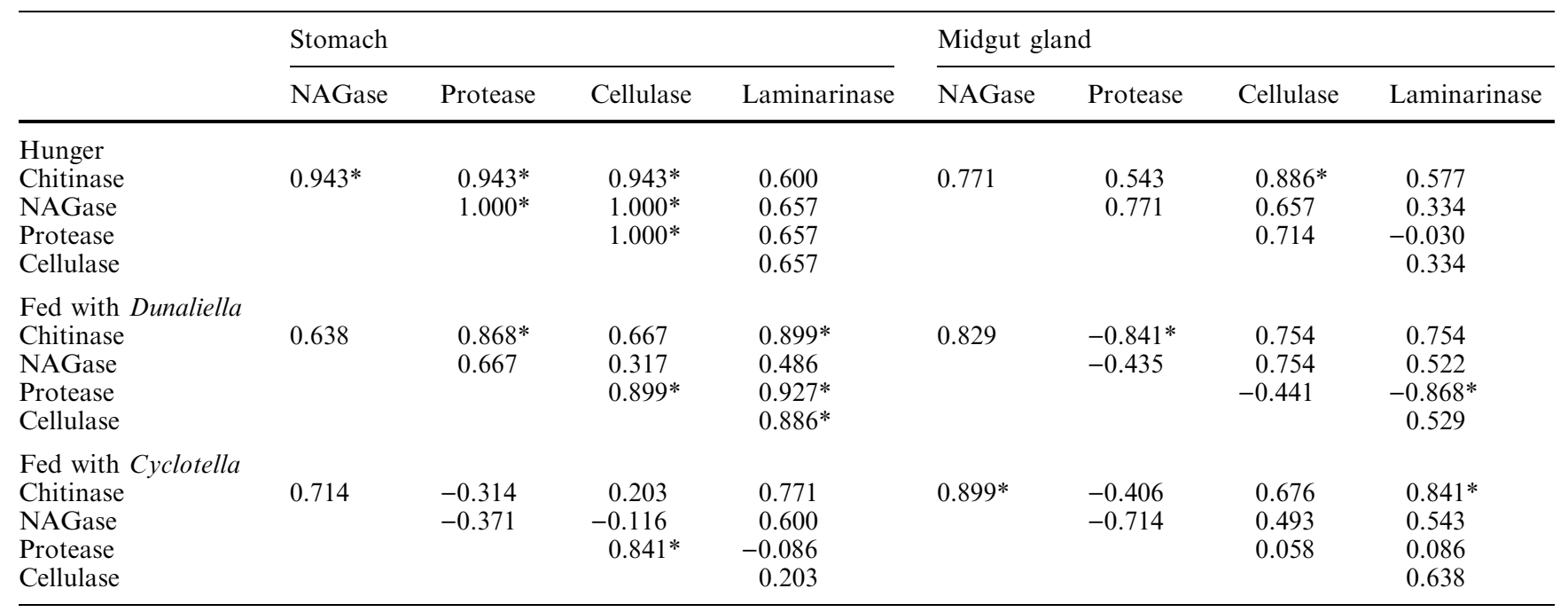

$* P<=0.05$ 
correlations appeared. The only significant positive relation was found between protease and cellulase.

In the midgut gland only a few statistically significant correlations were found as compared to the stomach. In starved animals these were between chitinase and cellulase. In animals fed with Dunaliella, significant correlations appeared between chitinase and protease as well as between protease and laminarinase; however, these were negative. In animals fed with Cyclotella, the courses of chitinase and NAGase, as well as chitinase and laminarinase, matched significantly and were positively correlated.

\section{Discussion}

The algae used for the feeding experiments needed to be easily cultured during the expedition, to have high growth rates, and to contain different amounts of chitin. Prior to the expedition, attempts were made to grow several arctic diatom species. The cultures had rather low growth rates, however. Thus, we decided to use boreal species which could be maintained at higher temperatures and which could sustain high growth rates and high densities in culture. The green alga $D$. bioculata was chosen as a non-chitinous species and the diatom $C$. cryptica was selected because of its high chitin content (Herth and Zugenmaier 1977). Cyclotella contains chitinous spines at the edge of the valves (Herth and Barthlott 1979). A description of the chitin-synthesizing apparatus of diatoms is given by Herth (1978). These typical "pores" or "strutted processes" are also used as criteria in species determination. Johansen and Fryxell (1985) found several Thalassiosira species in Antarctic waters using these criteria. Thus, chitin-containing diatoms are common in the Antarctic Ocean. Opalinski et al. (1997) found that krill prefer Thalassiosira species as food items.

Chitin in C. cryptica amounted to $11.6 \%$ of the dry weight, corresponding to $4 \mathrm{mg} \mathrm{l}^{-1}$ of culture. D. bioculata contained no chitin. In comparison, McLachlan et al. (1965) reported a chitin content of $31-38 \%$ in Thalassiosira fluviatilis and Lindsay and Gooday (1985) determined $4.9 \mathrm{mg}$ chitin $1^{-1}$ in cultures of the same species.

The food offered was accepted well as determined by the organ fullness indices. These were in the same range or higher than those for field samples, indicating a sufficient food supply during the experiments. However, the evaluation is not without problems. A certain element of subjectivity cannot be avoided and changing food composition can cause differences in colour and intensity. Empty organs have a slight yellowish coloration, corresponding to an index between 1 and 2, which explains the values for starved krill.

Containers for the maintenance of krill have to be large enough to allow the animals to move freely in the water and to ensure unhindered filtering. However, for longer experiments it is necessary to separate specimens, because cannibalism may occur (Ikeda and Dixon 1982). We observed cannibalism only occasionally when krill were maintained in small tanks and starved for more than 3 weeks. Otherwise there were no distinct behavioural differences between animals maintained in groups and those kept separately. Therefore, the maintenance conditions appeared to be favourable and should not have affected the results to a great extent.

Previous investigations of digestive enzyme activities in pelagic crustaceans have been restricted to extracts of whole animals (e.g. Mayzaud and Poulet 1978; Mayzaud and Mayzaud 1981; Hassett and Landry 1982; Tande and Slagstad 1982) or the midgut gland only (McConville et al. 1986). The complexity of the digestion process and interactions between midgut gland and the stomach can be explained only when both organs are investigated separately (Buchholz 1989). Furthermore, the adaptation of enzyme activity in the digestive organs to different feeding conditions requires a certain time. It is difficult to define appropriate experimental periods in advance, however. Thus, we designed our experiments to cover a range from 3 weeks in experiment 1 to a few days in experiment 3.

Relatively little difference was observed in the enzyme activity of the three differently fed groups in experiments 1 and 2. McConville et al. (1986) reported similar results for 1,3- $\beta$-D-glucanase in krill. Hassett and Landry (1982) suggested that high activities of digestive enzymes at low food concentrations are an adaptation to a patchy and thus unpredictable food supply. If a rich patch is found, krill are able to make use of this situation immediately. This suggestion is supported by our results. However, during the highly productive summer, starvation periods of 2-3 weeks seem unlikely, particularly as krill are fast and persistent swimmers (Kils 1983). Therefore, krill should be able to leave areas with low food concentrations to locate better food sources. Accordingly, variations of enzyme activity on a shorter time scale seem possible. We observed this in experiment 3. As in experiments 1 and 2, enzyme activity in the digestive organs increased during the short acclimation period before food was given. This increase probably corresponded to the organs being emptied. A filled stomach weighs $1-2 \mathrm{mg}$ depending on the size of the krill, a totally empty one only $20-30 \mu \mathrm{g}$. Consequently, the specific activity increases. Thereafter, activities in the stomach of the starved krill decreased considerably, whereas activities in the fed groups either increased steeply or at least remained at the same level. Towards the end of experiment 3 , values approached the situation described in experiments 1 and 2 . The activity patterns in the midgut gland were similar, but differences between starved and fed specimens were less distinct.

The temporal pattern of enzyme activity described above can be explained by the morphology and function of the digestive tract. Although a detailed study on the microscopic anatomy of the krill stomach exists (Ullrich et al. 1991), histological and cytological investigations of 
the midgut gland of euphausiids are rare and there have been no such investigations for E. superba. The following explanation is, therefore, based on the well-characterized digestive tract of systematically closely related decapods. Vogt (1985) described the histology and cytology of the midgut gland of Penaeus monodon and, in more detail, that of Astacus astacus (Vogt 1994), permitting to draw a general functional model of the digestive tract.

The stomach and midgut gland form a functional unit and are connected by a funnel. In the anterior region of the stomach (cardia) the food is ground and mixed with digestive enzymes from the midgut gland. In the posterior part of the stomach (pylorus) the crushed food is filtered and the filtrate is passed on into the midgut gland (Ullrich et al. 1991). The midgut gland consists of a system of blind-ending tubules which again consist of a unilayer epithelium with special cells for nutrient resorption (R-cells) and cells for enzyme synthesis (F-cells). Digestive enzymes are released directly into the tubuli-lumina. In contrast to mammals, enzymes are stored extracellularly in active form in the lumen of the digestive organs (Vogt et al. 1989). In crustaceans, the transfer of digestive enzymes from the midgut gland into the stomach may be facilitated by a net of muscle fibres surrounding the tubules. During the cyclic digestion process the food extract is pumped from the pylorus into the tubules of the midgut gland. Here nutrient absorption takes place and digestive enzymes are released into the lumina of the tubules. By contraction of the muscle fibres these enzymes are pumped actively from the tubules through the funnel into the pylorus. This description is also in close accordance with detailed investigations by Powell (1974) on thalassinid crustaceans (see also Dall and Moriarty 1983; Icely and Nott 1992). While feeding, digestion proceeds as described above. As digestion progresses, the stomach is emptied. When no additional food is ingested, the release of enzymes into the stomach is diminished and consequently the enzyme activity decreases. Simultaneously, enzyme biosynthesis in the midgut gland decreases but continues at a lower level. The continuously synthesized enzymes are released into the tubules and, it is suggested, they are transported passively through the funnel into the stomach where they accumulate. Consequently, enzyme activities in the stomach increase again when specimens starve for a longer period.

This explanation is supported by the results of the correlation analysis. High coefficients and most of the significant correlations were found in the stomachs of starved animals, which indicated the simultaneous course of activity of at least a number of digestive enzymes (see also Fig. 4). In comparison, the correlation matrix of the midgut gland enzymes from starved animals was more inconsistent as a result of diverging activity patterns of the enzymes. Additionally, with the exception of protease, no correlation was found between enzymes from the stomach and the midgut gland, indicating different time courses of enzyme activity.
Our results also indicate that the appearance of digestive enzymes is to a certain extent selective. Selective enzyme induction has been reported for many vertebrates and invertebrates. However, investigations with marine zooplankton gave variable results. Cox (1981) and Cox and Willason (1981) were able to induce laminarinase in feeding experiments with Euphausia pacifica and Calanus pacificus and Roche-Mayzaud et al. (1991) reported comparable results on a set of enzymes in the copepod Acartia clausi. Head and Conover (1983) also induced protease, laminarinase and amylase by feeding algae to Calanus hyperboreus. However, when particulate laminarin was fed, no induction occurred. In contrast, Hassett and Landry (1982) reported decreasing activities of laminarinase, cellobiase and maltase in Calanus pacificus fed with varying amounts of algae. Van Wormhoudt et al. (1980) demonstrated in Palaemon serratus that maximum specific activities of amylase and protease did not coincide with maximum substrate concentration but appeared at intermediate levels. Furthermore, variation in the response of digestive proteases of Penaeus vannamei to different levels and sources of protein were related to animal size (Lee et al. 1984).

Field investigations have also been inconsistent. Mayzaud and Conover (1976) reported a significant correlation between the activities of several digestive enzymes in total zooplankton catches and the composition of particulate matter in the water-column. In $E$. superba, however, the correlation between the potential nutrient composition and some related enzymes was negative (Mayzaud et al. 1985).

Our correlation analysis showed an equidirectional course of the two chitinolytic enzymes chitinase and NAGase, as well as chitinase with laminarinase in the midgut gland, the site of enzyme synthesis, when krill was fed with Cyclotella (chitinous) but not when fed with Dunaliella. These patterns reflect the content of the substrate of the algal food source. Besides the possession of chitinous spines, Cyclotella contained more 1,3- $\beta$-Dglucan than Dunaliella. Laminarin is one of the major carbohydrates in many phytoplankton species, particularly in diatoms, and thus a rich energy source for herbivorous plankton feeders. Enzymes cleaving laminarin are common in many zooplankton species. The ability to increase enzyme activity in response to the substrate concentration can be considered an efficient adaptation to environmental conditions, typical for Antarctic waters, which require rapid and effective nutrient utilization. In this respect it appears to be useful to maintain high levels of the whole set of digestive enzyme activity but, additionally, to increase the activity of specific enzymes for the utilization of extra amounts of substrates.

The activity patterns of chitinases in starved and fed specimens are similar to those of other digestive enzymes. Chitinases are capable of utilizing valuable nutrients from algal sources but are just as important when krill switch to carnivorous feeding. The decrease of activity in the stomach during starvation can be explained by diminished secretion from the midgut gland into the 
stomach. The relatively high and constant activities in the midgut gland seem to provide a stock of digestive potential that can be released when a food patch is met.

Acknowledgements We are grateful to the staff of the research vessel FS Meteor for excellent support in the field and Ms. Sonja Böhm for technical assistance in the laboratory. Fruitful discussions were held with Dr. Gerrit Peters, Dr. Ralf-A. Vetter and Dr. Matthew Dring. Dr. Malte Elbrächter gave us valuable information on the cultivation of algae and Dr. Bernd Überschär inoculated the algae cultures during the preceding expedition (Met 11/3). This work was supported by a grant from the German Research Council (DFG Bu 548/2) and was completed in the Department of Zoology of the Institut für Meereskunde in Kiel.

\section{References}

Atkinson A, Snÿder R (1997) Krill-copepod interactions at South Georgia, Antarctica. I. Omnivory by Euphausia superba. Mar Ecol Prog Ser 160:63-76

Bradford MM (1976) A rapid and sensitive method for the quantitation of microgram quantities of protein utilizing the priciple of protein-dye binding. Anal Biochem 72:248-254

Buchholz F (1989) Moult cycle and seasonal activities of chitinolytic enzymes in the integument and digestive tract of the Antarctic krill, Euphausia superba. Polar Biol 9:311-317

Buchholz C, Buchholz F (1989) Ultrastructure of the integument of a pelagic crustacean: moult cycle related studies on the Antarctic krill, Euphausia superba. Mar Biol 101:355-365

Buchholz F, Saborowski R (1996) A field study on the physiology of digestion in the Antarctic krill, Euphausia superba, with special regard to chitinolytic enzymes. J Plankton Res 18: 895906

Cox JL (1981) Laminarinase induction in marine zooplankton and its variability in zooplankton samples. J Plankton Res 3:245256

Cox JL, Willason SW (1981) Laminarinase induction in Calanus pacificus. Mar Biol Lett 2:307-311

Dall W, Moriarty DJW (1983) Functional aspects of nutrition and digestion. In: Mantel LH (ed) The biology of crustacea, vol 5. Internal anatomy and physiological regulation. Academic Press, New York, pp 215-261

Donachie SP, Saborowski R, Peters G, Buchholz F (1995) Bacterial digestive enzyme activity in the stomach and hepatopancreas of Meganyctiphanes norvegica (M. Sars, 1857). J Exp Mar Biol Ecol 188:151-165

El-Sayed SZ, Taguchi S (1981) Primary production and standing crop of phytoplankton along the ice-edge in the Weddell Sea. Deep Sea Res 28(a):1017-1032

El-Sayed SZ, Weber LH (1982) Spatial and temporal variations in phytoplankton biomass and primary productivity in the Southwest Atlantic and the Scotia Sea. Polar Biol 1:83-90

Guillard RRL, Ryther JH (1962) Studies of marine planktonic diatoms. I. Cyclotella nana Hustedt and Detonula confervacea (Kleve). Gran Can J Microbiol 8:229-239

Hamner WM, Hamner PP, Strand SW, Gilmer RW (1983) Behavior of Antarctic krill, Euphausia superba: chemoreception, feeding, schooling and molting. Science 220:433-435

Hassett RP, Landry MR (1982) Digestive carbohydrase activities in individual marine copepods. Mar Biol Lett 3:211-221

Head EJH, Conover RJ (1983) Induction of digestive enzymes in Calanus hyperboreus. Mar Biol Lett 4:219-231

Herth W (1978) A special chitin-fibril-synthesizing apparatus in the centric diatom Cyclotella. Naturwissenschaften 65:260-261

Herth W, Barthlott W (1979) The site of $\beta$-chitin fibril formation in centric diatoms. I. Pores and fibril formation. J Ultrastruct Res 68:6-15
Herth W, Zugenmaier P (1977) Ultrastructure of the chitin fibrils of the centric diatom Cyclotella cryptica. J Ultrastruct Res 61:230239

Huntley ME, Nordhausen W, Lopez MDG (1994) Elemental composition, metabolic activity and growth of Antarctic krill Euphausia superba during winter. Mar Ecol Prog Ser 107:2340

Icely JD, Nott JA (1992) Digestion and absorption: digestive system and associated organs. In: Harrison FW, Humes AG (eds) Microscopic anatomy of invertebrates, vol 10. Decapod crustacea. Wiley-Liss, New York, pp 147-201

Ikeda T, Dixon P (1982) Observations on moulting in Antarctic krill (Euphausia superba Dana). Aust J Mar Freshwat Res 33:71-76

Johansen JR, Fryxell GA (1985) The genus Thalassiosira (Bacillariophyceae): studies on species occurring south of the Antarctic Convergence Zone. Phycologia 24:155-179

Kils U (1983) Swimming and feeding of Antarctic krill, Euphausia superba - some outstanding energetics and dynamics, some unique morphological details. Ber Polarf Sonderh 4:130-155

Lancraft TM, Hopkins TL, Torres JJ, Donnelly E (1991) Oceanic micronectonic/makrozooplanktonic community structure and feeding in ice covered Antarctic waters during the winter (AMERIEZ 1988). Polar Biol 11:157-167

Lee PG, Smith LL, Lawrence AL (1984) Digestive proteases of Penaeus vannamei Boone: relationship between enzyme activity, size and diet. Aquaculture 42:225-239

Lindsay GJH, Gooday GW (1985) Action of chitinase on spines of the diatom Thalassiosira fluviatilis. Carbohydr Polym 5:131-140

Mayzaud P, Conover RJ (1976) Influence of potential food supply on the activity of digestive enzymes of neritic zooplankton. In: Persoone G, Jaspers E (eds) Proceedings of the 10th European Symposium of Marine Biology, vol 2, Ostend 1975. Universa Press, Wetteren, pp 415-427

Mayzaud P, Farber-Lorda J, Corre MC (1985) Aspects of the nutritional metabolism of two Antarctic euphausiids: Euphausia superba and Thysanoessa macrura. In: Siegfried WR, Condy PR, Laws RM (eds) Antarctic nutrient cycles and food webs. Springer, Berlin Heidelberg, pp 330-338

Mayzaud P, Mayzaud O (1981) Kinetic properties of digestive carbohydrases and proteases of zooplankton. Can J Fish Aquat Sci 38:535-543

Mayzaud P, Poulet SA (1978) The importance of the time factor in the response of zooplankton to varying concentrations of naturally occurring particulate matter. Limnol Oceanogr 23:11441154

McConville MJ, Ikeda T, Bacic A, Clarke AE (1986) Digestive carbohydrases from the hepatopancreas of two Antarctic euphausiid species (Euphausia superba and E. crystallorophias). Mar Biol 90:371-378

McLachlan J, McInnes AG, Falk M (1965) Studies on the chitan (chitin: poly-n-acetylglucosamine) fibers of the diatom Thalassiosira fluviatilis Hustedt. I. Production and isolation of chitan fibers. Can J Bot 43:707-713

Morgan WTJ, Elson LA (1934) A colorimetric method for the determination of n-acetylglucosamine and n-acetylchondrosamin. Biochem J 28:988-995

Morris DJ, Ward P, Clarke A (1983) Some aspects of feeding in the Antarctic krill, Euphausia superba. Polar Biol 2:21-26

Opalinski KW, Maciejewska K, Georgieva LV (1997) Notes on food selection in the Antarctic krill, Euphausia superba. Polar Biol 17:350-357

Pakhomov EA, Perissinotto R, Froneman PW, Miller DGM (1997) Energetics and feeding dynamics of Euphausia superba in the South Georgia region during the summer of 1994. J Plankton Res 19:399-423

Powell RR (1974) The functional morphology of the foreguts of the thalassinid crustaceans, Callianassa californiensis and Upogebia pugettensis. Univ Calif Publ Zool $102: 1-41$ 
Price HJ, Boyd KR, Boyd CM (1988) Omnivorous feeding behavior of the Antarctic krill Euphausia superba. Mar Biol 97:6777

Roche-Mayzaud O, Mayzaud P, Biggs DC (1991) Medium-term acclimation of feeding and of digestive and metabolic enzyme activity in the neritic copepod Acartia clausi. I. Evidence from laboratory experiments. Mar Ecol Prog Ser 69:25-40

Roe HSJ, Shale DM (1979) A new multiple rectangular midwater trawl (RMT $1+8 \mathrm{M}$ ) and some modifications to the Institute of Oceanographic Sciences' RMT 1 + 8. Mar Biol 50:283-288

Saborowski R, Buchholz F, Vetter R-AH, Wirth SJ, Wolf GA (1993) A soluble, dye-labelled chitin derivative adapted for the assay of krill chitinase. Comp Biochem Physiol 105B:673-678

Tande KS, Slagstad D (1982) Ecological investigations on the zooplankton community of Balsfjorden, northern Norway. Seasonal and short-time variations in enzyme activity in copepodite stage V and VI males and females of Calanus finmarchicus (Gunnerus). Sarsia 67:63-68
Ullrich B, Storch V, Marschall HP (1991) Microscopic anatomy, functional morphology, and ultrastructure of the stomach of Euphausia superba Dana (Crustacea, Euphausiacea). Polar Biol 11:203-211

Van Wormhoudt A, Ceccaldi HJ, Martin BJ (1980) Adaptation de la teneur en enzymes digestives del'hepatopancreas de Palaemon serratus (Crustacea, Decapoda), a la composition d'aliments experimentaux. Aquaculture 21:63-78

Vogt G (1985) Histologie und Cytologie der Mitteldarmdrüse von Penaeus monodon (Decapoda). Zool Anz Jena 215:61-80

Vogt G (1994) Life-cycle and functional cytology of the hepatopancreatic cells of Astacus astacus (Crustacea, Decapoda). Zoomorphology 114:83-101

Vogt G, Stöcker W, Storch V, Zwilling R (1989) Biosynthesis of Astacus protease, a digestive enzyme from crayfish. Histochemistry 91:373-381

Wilkinson L (1989) SYSTAT: the system for statistics. SYSTAT, Evanston, IJL 